\title{
Seasonal reproductive health of flounder Platichthys flesus exposed to sewage effluent
}

\author{
C. M. Lye*, C. L. J. Frid, M. E. Gill \\ Dove Marine Laboratory, University of Newcastle upon Tyne, Cullercoats, North Shields NE30 4PZ, United Kingdom
}

\begin{abstract}
Indicators of environmental oestrogen exposure in male and female wild flounder Platichthys flesus were followed over the annual reproductive cycle. Fish were obtained from the Tyne estuary, UK, which receives effluent from a large sewage treatment works and several other anthrophogenic sources and the Solway Firth, UK, which receives only low levels of sewage effluent. Vitellogenin (vtg), a female-specific protein, was present in the plasma of up to $94 \%$ of males from the Tyne and was accompanied by inhibited spermatogenesis and the incidence of pathological testicular abnormalities. The vtg levels in males are independent of the seasonal cycle. Female flounders from the Tyne exhibited increased vtg levels and a higher proportion of degenerating oocytes than Solway Firth females. This study provides limited evidence that wild populations of flounders showing oestrogenic responses are also suffering reproductive disturbances but the degree of alteration varies during the seasonal reproductive cycle.
\end{abstract}

KEY WORDS: Platichthys flesus - Vitellogenın - Sewage Oestrogen - Testicular morphology - Ovarian development

\section{INTRODUCTION}

The disruption of hormonal and reproductive systems in humans and wildlife by anthropogenic and naturally occurring chemicals present in the environment has become a major topic of scientific research and the focus of considerable scientific attention in recent years (for reviews see McLachlan 1981, 1985, Colborn \& Clement 1992, Harrison et al. 1995, Toppari et al. 1995, Kavlock et al. 1996, EPA 1997). Evidence for increasing levels of substances that can cause feminising or oestrogenic effects in the environment during the past half-century comes from several sources, notably an increasing consumption of oestrogens in human diet (Sharpe \& Skakkebæk 1993, Carlsen et al. 1995) and the expanding use of many different groups of synthetic chemicals (e.g. some PCBs, DDT, phthalates, alkylphenols, and Bisphenol-A), many of which have been shown to exhibit oestrogenic activity and/or degrade to persistent metabolites which are oestrogenic (Brotons et al. 1995, Jobling et al. 1995, Soto et al. 1995, Harris et al. 1997).

\footnotetext{
·E-mail: christina.m.lye@opc.simis.com
}

An observable and quantifiable effect of exposure to oestrogens is the stimulation of vitellogenin (vtg) synthesis. Vtg is the major precursor of yolk proteins in all oviparous vertebrates and is synthesised by the liver in response to circulating oestrogens (Bromage \& Cumaranatunga 1988). Although vtg is a female-specific protein it can be induced in males if they are treated with exogenous oestrogens and thus the presence of vtg in the plasma of males is a useful biomarker for oestrogenicity of chemicals (Heppel et al. 1995, Korach \& McLachlan 1995, Sumpter \& Jobling 1995). It is now becoming evident that most domestic sewage effluents entering rivers in the UK are strongly oestrogenic to caged male trout Oncorhynchus mykiss where formation of vtg in plasma has been widely observed (Purdom et al. 1994). These effects are also present in the receiving waters (Harries et al. 1996, 1997) and have been ascribed mainly to natural oestrogens, largely from human sources (Waldock et al. 1997) but also to oestrogen-mimicking substances (Harries et al. 1997).

Recently it has been demonstrated that wild marine flounder Platichthys flesus taken from an estuary receiving large inputs of sewage effluent showed ele- 
vated plasma levels of vtg and gross abnormalities in testis morphology (Lye et al. 1997). This observation, coupled with a reported high incidence of inter-sex gonads (e.g. the simultaneous presence of female and male characteristics) and increased levels of $\mathrm{vtg}$, both effects linked to discharges of sewage effluent, in roach Rutilus rutilus, and to a certain degree also in bream Abramis abrama, gudgeon Gobio gobio and chub Leuciscus cephalus from a number of UK rivers (Jobling et al. 1997, Environment Agency UK 1998), suggests that wild fish exposed to oestrogenic substances are suffering oestrogenic effects which can result in reproductive disturbance. However, the physiological consequences of $\mathrm{vtg}$ in wild male fish and of additional exposure to oestrogens on females are as yet unclear and warrant further investigation.

The flounder Platich thys flesus is widely distributed in estuaries and coastal zones. Its demersal behaviour and resuspension of the substrate during swimming activity makes this species especially vulnerable to sediment-associated pollution normally occurring in high concentrations in the recipients of land-based point sources, river run-offs and urban areas (Goksøyr et al. 1996). Most oestrogenic substances are both strongly lipophilic and sorptive (Ahel et al. 1993) and are therefore likely to accumulate in the organically rich sediments of an estuary. Flounders are directly exposed to water-borne contaminants via their gills,

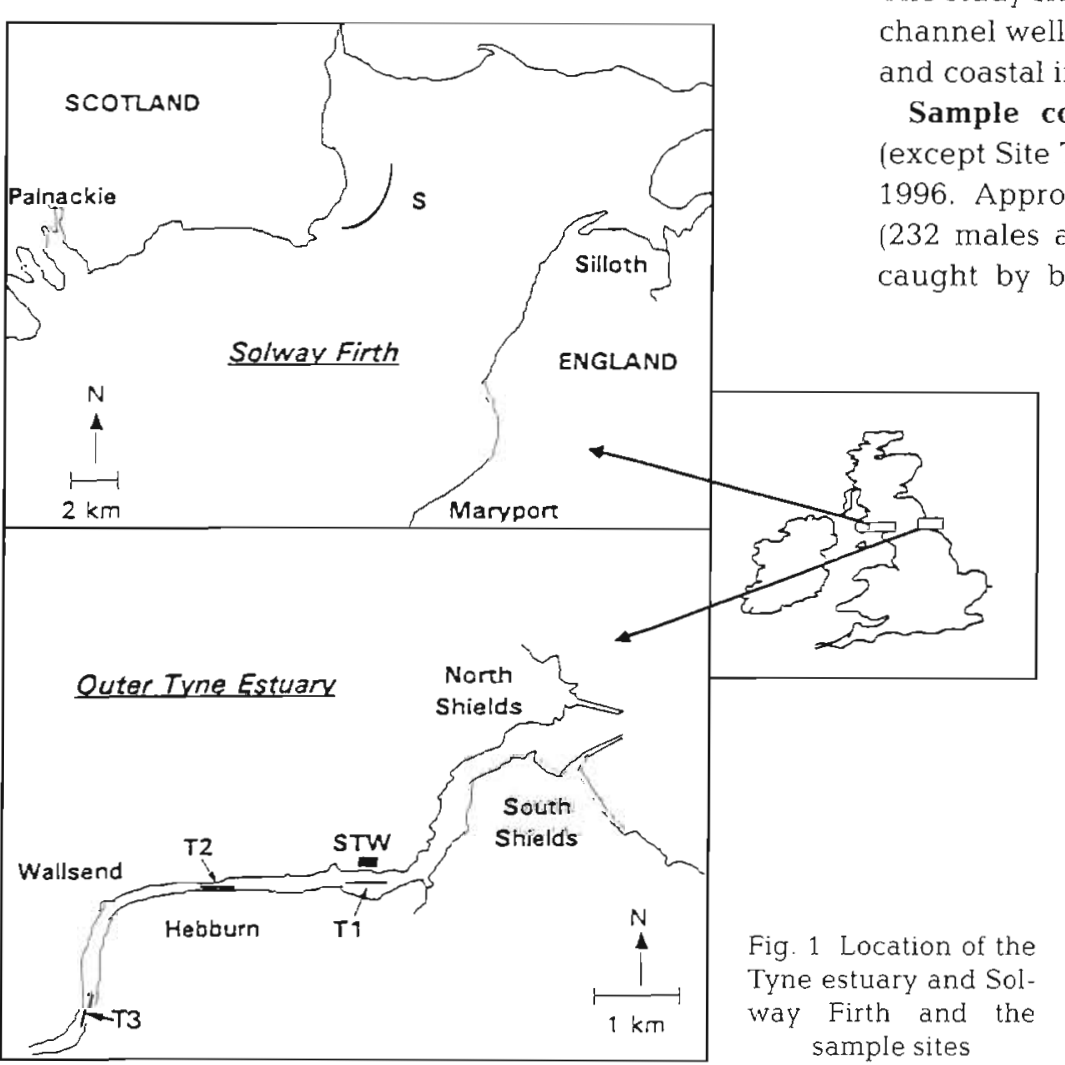

skins and fins and through direct contact with contaminated sediment, for example through food (Berge \& Brevik 1996). This study follows the changes in both male and female flounders over the annual reproductive cycle to establish the effect of exogenous oestrogens on the reproductive biology of this estuarine fish species.

\section{METHOD}

Study sites. Flounders were collected adjacent to the outfall of the major sewage treatment works (STW) at Howdon in the Tyne estuary, UK (Site T1) and 2.5 and $5 \mathrm{~km}$ upstream of this site (T2, T3; Fig. 1). The STW in the Tyne provides primary treatment to sewage from a large catchment zone $\left(2935 \mathrm{~km}^{2}\right)$ and a population of about 1.25 million people. The supernatant from the settlement tanks is discharged into the estuary, with an average dry weather flow exceeding $240000 \mathrm{~m}^{3} \mathrm{~d}^{-1}$ (Environment Agency UK pers. comm.), and the settled sludge is disposed of at sea. For comparison, fish were taken from the Solway Firth, UK, which drains a catchment covering a sparsely populated region with only 1 large (i.e. serving a population equivalent of $>100000$ ) STW on its tributaries. There are also small treatment plants serving rural communities often comprising a few houses (Solway Firth Partnership 1996). The study site selected (Site S) was in the main estuary channel well away from inputs from tributary estuaries and coastal industrial discharges (Fig. 1).

Sample collection. Sampling took place in July except Site T3), September, December 1995 and April 996. Approximately 640 sexually mature flounders 232 males and 407 females, length $>250 \mathrm{~mm}$ ) were am trawl and blood-samples taken for subsequent serum analysis according to procedures described in Lye et al. (1997). In the laboratory individual fish lengths and weights were recorded after which the fish were dissected for examination of internal organs. Liver and gonad weights were recorded and the hepatosomatic and gonadosomatic index (e.g. HSI, GSI; organ weight $[\mathrm{g}] /$ body weight $[\mathrm{g}]$ ) were calculated. Gonads were examined macroscopically for gross changes in morphology (see Lye et al. 1997). Gonad samples were also preserved for histological examinations (see below).

Fixation of fish tissue. Testicular tissues with suspected lesions $(n=30)$ were fixed in $10 \%$ formalin and in paraffin. Serial sections $(10 \mu \mathrm{m})$ were 
cut and stained with haematoxylin and eosin. From 4 samples showing eosinophilic amorphous material in testes by microscopic examination additional sections were cut and Crystal Violet was used to stain for the presence of amyloids, a group of diverse extra-cellular protein deposits associated with many different diseases (Kisilevsky 1994). Ovarian tissues with suspected lesions $(n=25)$ were fixed in formalin saline, processed and cut using a freezing microtome following standard techniques.

Serum analysis. Identification of vtg was carried out as described by Lye et al. (1997). SDS-polyacrylamide gel electrophoresis (SDS-PAGE) was routinely performed and the protein quantified by scanning densitometry.

Statistical analysis. Data were checked for normality and variance homogeneity and, where necessary (GSI, HSI), transformed $\left(\log _{10}\right)$ prior to analysis. The Tukey multiple comparison test was used after initial 2-way analysis of variance (ANOVA, $p<0.05$ ) using the General Linear Model (GLM) Procedure in the Minitab Statistical Package (Zar 1984). Chi-square tests were used for testing between site differences in frequencies. When there were no proven significant differences between the sites in the Tyne, data for these sites were pooled.

\section{RESULTS}

\section{Serum analysis}

The presence of vtg in serum was found in male flounder ( $\mathrm{n}=232$ ) from both sites investigated, the highest prevalence $(94 \%)$ in male flounder from the Tyne (April 1996) and the lowest prevalence (27\%) in flounder from Solway Firth (September 1995) (Table 1). Quantification of vtg showed that there was a significant difference in plasma vtg levels of male flounders between the sites but not between sampling occasions (2-way ANOVA, site: $F=20.7, \mathrm{p}<0.05$; date: $F=1.8$, $p>0.05$ ) (Fig 2). Thus, significantly higher plasma vtg

Table 1. Percentage of male flounders Platichthys flesus from sites in the Tyne (T1, T2, T3) and Solway Firth (S) with vitellogenin (vtg) present in their plasma in July, September, December 1995 and April $1996(n=232)$

\begin{tabular}{|lcccc|}
\hline Site & Jul 1995 & Sep 1995 & Dec 1995 & Apr 1996 \\
\hline T1 & $88 \%$ & $85 \%$ & $81 \%$ & $88 \%$ \\
T2 & $82 \%$ & $64 \%$ & $85 \%$ & $95 \%$ \\
T3 & $\%$ & $73 \%$ & $75 \%$ & $78 \%$ \\
S & $40 \%$ & $27 \%$ & $37 \%$ & $50 \%$ \\
Not sampled in July 1995 & & \\
\hline
\end{tabular}

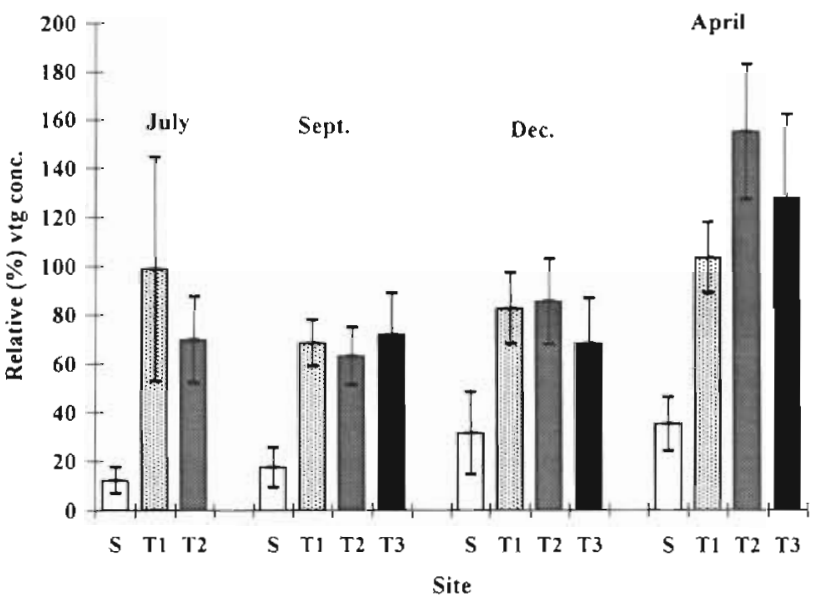

Fig. 2. Levels of vitellogenin (vtg) (mean $\pm \mathrm{SE}$ ) in plasma of male flounders Platichthys flesus from sites in the Tyne Estuary (T1, T2, T3) and the Solway Firth (S). Values are expressed as a percentage of the protein level in a control female

levels were found in male flounders from the Tyne compared to those from Solway Firth on all sampling occasions (Tukey's, $p<0.05$ ) except for Site T3 in December 1995. Some individual flounder from the Tyne sites in April showed vtg plasma levels similar to those of gravid females (>300 units). Significantly higher levels were also found at Site T1 compared to Site T2 and T3 in the Tyne in April (Tukey's, p > 0.05) (Fig. 2).

In female flounders $(\mathrm{n}=407)$ vtg plasma levels varied significantly both between sites and sampling occasions (2-way ANOVA, site: $F=11.9, p<0.05$; date: $F=34.5, p<0.05$ ) (Fig 3 ), the seasonal reproductive cycle effecting vtg levels in females from both sites, with peak vtg levels in April. Significantly higher plasma levels were found in female flounders from the Tyne compared to those in Solway Firth in September

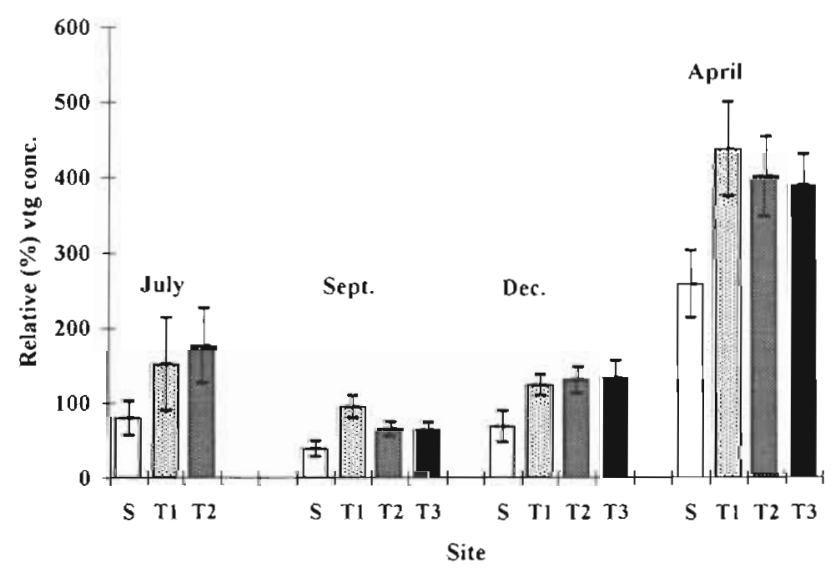

Fig. 3. Levels of $v \operatorname{tg}($ mean $\pm S E$ ) in plasma of female flounders Platichthys flesus from sites in the Tyne Estuary (T1, T2, T3) and the Solway Firth (S). Values are expressed as a percentage of the protein level in a control female 
(T1), December and April (Tukey's, p < 0.05). Apart from significantly higher levels in female fish from Site $\mathrm{T} 1$ in the Tyne in September, no significant difference was found between sites within the Tyne (Tukey's, $\mathrm{p}<0.05$ ).

\section{Testicular and ovarian gross morphology}

Abnormalities of testis morphology were found in a substantial proportion ( 53 to $67 \%$ ) of the examined flounders from sites in the Tyne $(n=172)$ whereas a significantly lower prevalence (maximum of $12 \%$ ) was observed in testes from male flounders from the Solway Firth $\left(\mathrm{n}=70\right.$; chi-square, $\left.\chi^{2}=25.8, \mathrm{p}<0.05\right)$ (Fig. 4). These differences were apparent on all sampling occasions. No differences were found between sampling occasions or between the sites within the Tyne (Fig. 4). The condition of the testis of flounder from the Tyne was characterised by truncated lobes, lack of lobular structure and a thickening of connective tissue surrounding the testis (see also Lye et al. 1997).

Abnormalities in ovarian morphology were observed in females from all sites investigated (Fig. 5). A significantly higher prevalence was found in females from the Tyne estuary (up to $36 \%, \mathrm{n}=292$ ) compared to females from Solway Firth (maximum of $12 \%, n=115$ ) (chi-square, $\chi^{2}=18.9, p<0.05$ ). This difference was apparent in September, December and April; gross ovarian abnormalities being absent in July (Fig. 5). The frequency of abnormal ovaries varied between sam-

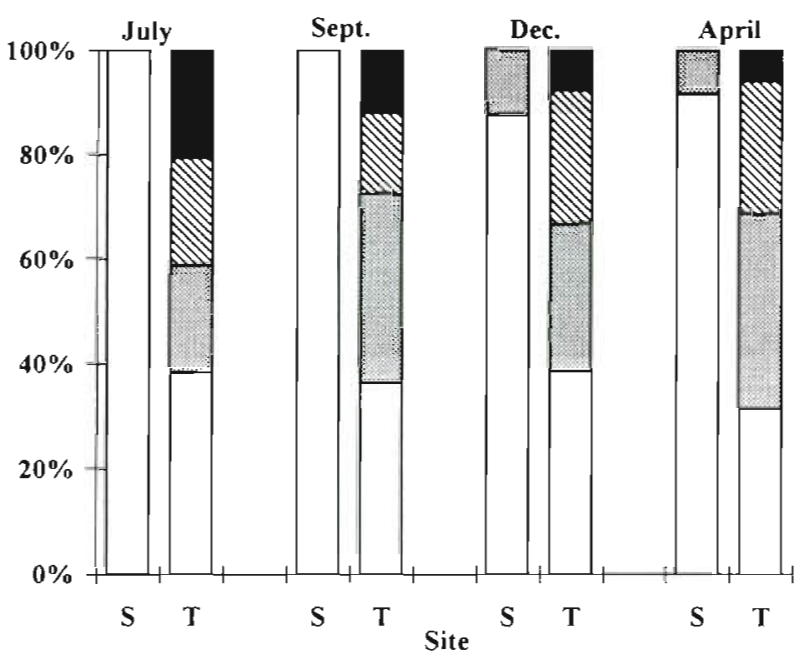

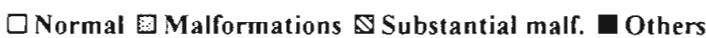

Fig. 4. Frequency $(\%)$ of testis malformations found in flounder Platichthys flesus $(n=232)$ from sites in the Tyne Estuary (T1, T2, T3) and the Solway Firth (S) in July, September, December (1995) and April (1996). (Nomal: elongated testis; Malformed: altered shape; Others: appearance of cysts/growth; blood-filled sperm duct; see Lye et al. 1997) pling occasions and similar levels of incidence were recorded at all sites within the Tyne (Fig. 5). Gross morphological examinations of ovaries revealed that fish taken from the Tyne exhibited abnormal ovaries consisting of large masses of aggregated and deformed oocytes sometimes accompanied by serious degeneration of the ovarian tissue in one or both gonads, the most prominent characteristics of these ovaries being the distinct yellow to green colour of the oocytes. Abnormalities in ovaries in Solway Firth were restricted to occasional discoloured and deformed oocytes ( 1 to 10 oocytes per fish).

\section{Qualitative examination of testis histology}

Abnormal testes $(\mathrm{n}=30$ ) from Tyne flounders, in all cases also showing detectable levels of vtg in their blood plasma, were examined from the 3 stages of spermatogenesis: proliferative cells (spermatogonia I, II), meiotic cells (spermatocytes I, II) and ripe cells (spermatids, spermatozoa). Normally, the histological picture of the testis of flounder presents a well-organised structure through all developmental stages, the interstitial tissue surrounding the testis lobules becoming distended and thin as the lobule lumen fills up with spermatogenetic elements (Janssen et al. 1996). In contrast, abnormal testes in proliferation (sampled in April/May), from flounder showing the highest levels of vtg, were generally characterised by disorganised lobules, a connective tissue thickening and vacuolation of the lobule wall, and the presence of spermatozoa remains in the lobular lumen (Figs. $6 \&$ 7). The lobules were typically devoid of germ cells and contained few cysts of spermatogenetic elements. In some cases,

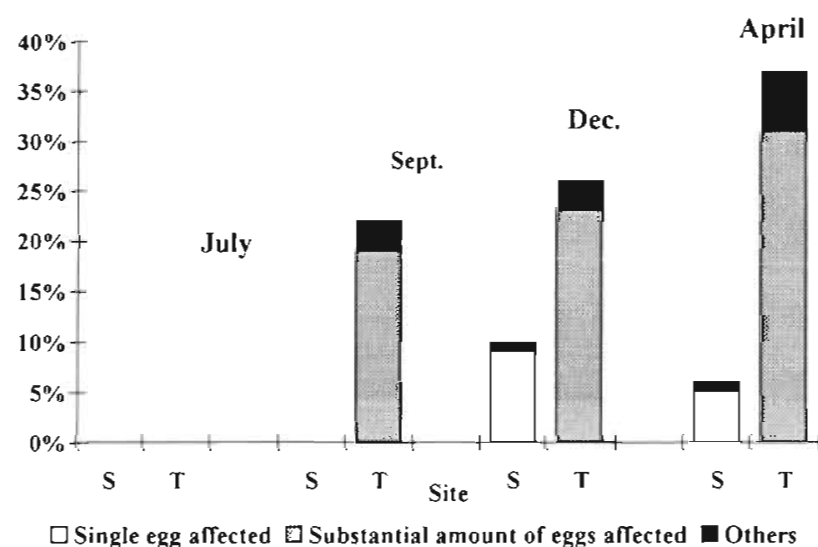

Fig. 5. Frequency $(\%)$ of oocyte malformations found in flounder Platichthys flesus ( $\mathrm{n}=407$ ) from sites in the Tyne estuary (total T1, T2, T3) and the Solway Firth (S) in July, September, December (1995) and April (1996). (Others. lymphocystis, green, soft tissue, blood-filled ovaries, degeneration) 


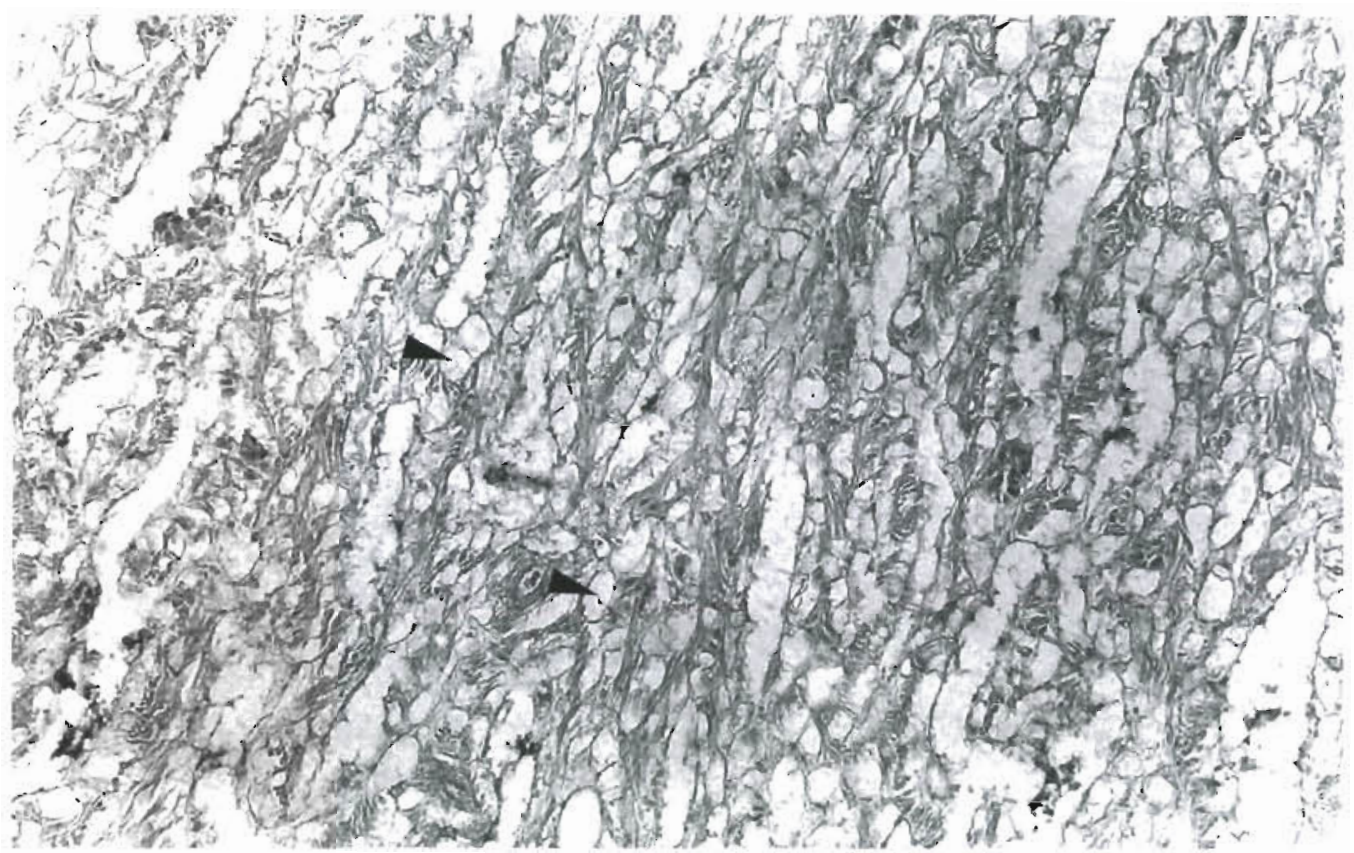

Fig. 6. Photomicrographs of testicular tissue from testes in proliferation obtained from flounders Platichthys flesus, showing high levels of vtg. Note poorly organised lobule structure, fibrosis, thickened and highly vacuolated lobule walls (arrowheads) accompanied by a reduced number of, or the absence of, germinal cells. Haematoxylin/eosin $(\times 160)$

lobules were fully converted into fibrous tissue resulting in the absence or reduction in germ cells (Fig 6). Frequently observed within or around the testis lobules was the accumulation of amorphous eosino- philic structures (Fig. 7). The presence of amyloids could not be confirmed using staining with Crystal Violet thus the significance of these eosinophilic structures is unknown.

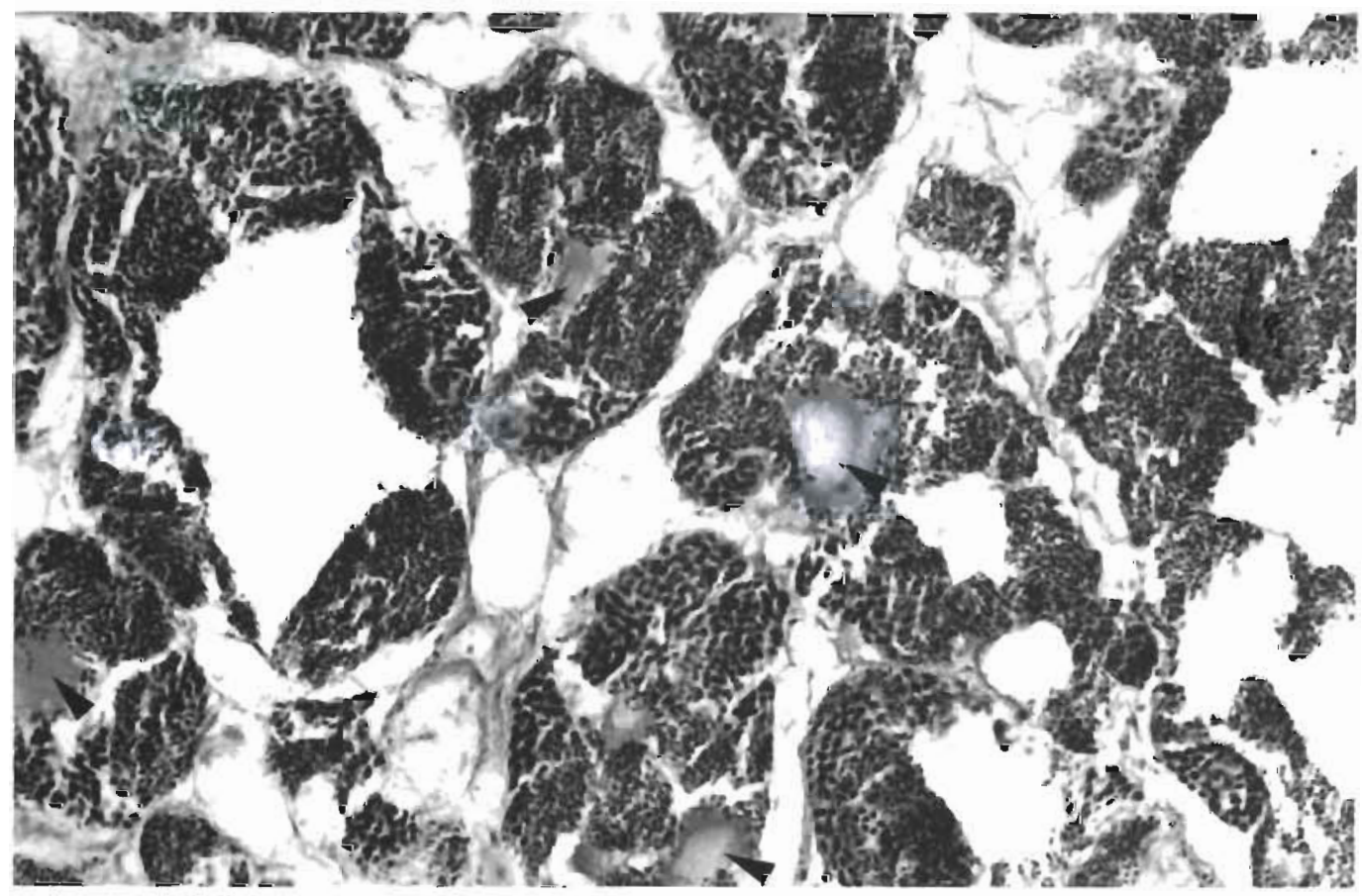

Fig. 7. Photomicrographs of testicular tissue from testes in proliferation obtained from flounders Platichthys flesus, showing high levels of vtg. Note fibrosis and deposition of amorphous eosinophilic extra-cellular material in the lumen (arrowheads). Haematoxylin/eosin $(\times 250)$ 
Spermatogenesis was well under way in Tyne fish testes examined at a later stage of the testicular cycle (sampled in October) and was characterised by the presence of spermatocytes. Despite the increase of germ cells, thickened lobule walls were still present and the lobules varied in size (Fig. 8). Vacuolation were also observed in these abnormal testes (Fig. 8). Testes containing mature sperm. (sampled in December/January) revealed some changes in testicular morphology (e.g. partly thickened lobule walls and the presence of amorphous materials) whereas other parts of the testes showed normal testicular development. and become granular (Fig, 10a). Fibroblast-like cells and a vast number of phagocytic cells extensively infiltrated the ovary and yellow pigments characteristic of the late stage of the atretic process (Dodd 1983) were frequently observed amongst these cells. Degenerating oocytes were present in large aggregates encapsulated by a membrane of several cell layers (Fig. 10b). Development of new oocytes was not observed within these structures. Degenerated oocytes were more frequently observed in ovaries in advanced vitellogenesis (sampled in December/January) than ovaries in early vitellogenesis (sampled in September).

\section{Qualitative examination of ovarian histology}

Ovaries of flounders examined from the Tyne ( $\mathrm{n}=$ 25 ) consisted of oocytes in early and advanced vitellogenesis. Oocytes in the vitellogenic stage are normally characterised by densely packed yolk granules, the nucleus located at the centre of the oocyte and the oocyte surrounded by zona radiata and the follicle layers (Fig. 9). In contrast, the structure of oocytes in abnormal ovaries was atypical and breakdown of developing oocytes was observed along with their conversion to fully formed corpora atretica (e.g. degenerating oocytes) (Fig. 10). In these oocytes zona radiata was ruptured and the interior of oocytes invaded by phagocytic cells resulting in the breakdown of yolk globules. The oocyte nucleus had also broken down

\section{Gonadosomatic index}

The mean GSI-values of female flounders varied significantly between sites and sampling occasions (2-way ANOVA, site: $F=14.2, p>0.05$; date: $F=16.1$, $\mathrm{p}<0.05)$. The latter reflects the annual reproductive cycle with gonad weight increasing to a maximum in April. Significantly larger mean GSI-values were found in female flounders from the Tyne in September and April compared to those in Solway Firth and in female flounders from Solway Firth in December compared to those in the Tyne (Fig. 11). In addition, there was a significant difference in September between the sites within the Tyne (Tukey's, $p<0.05$ ). The mean GSI-values of male flounders varied significantly between site and sampling occasions (2-way ANOVA,

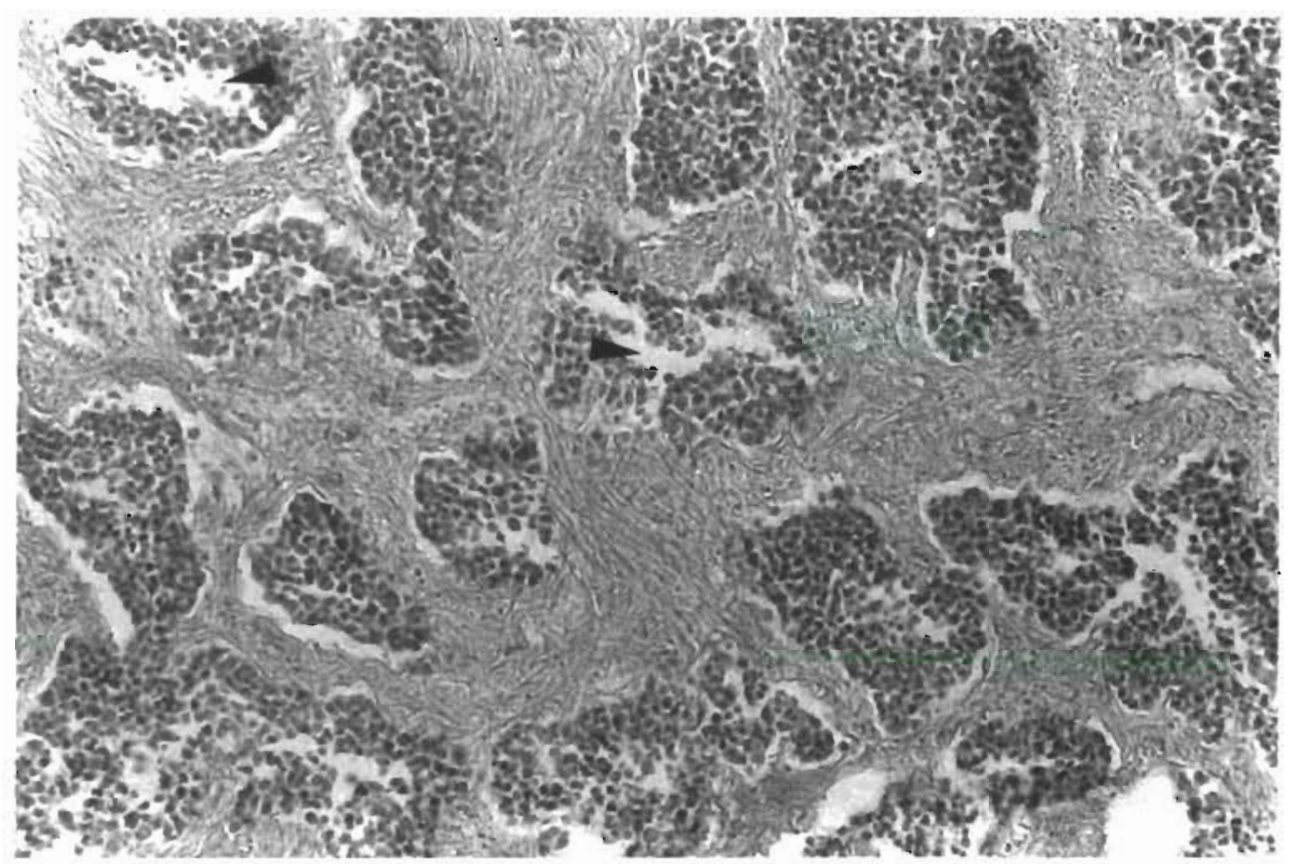

Fig. 8. Photomicrographs of testicular tissue from testes in meiosis, flounders Platichthys flesus, showing thickening of connective tissue in lobule walls, poorly organised lobule structure and varying lobule size and the presence of vacuolated cells (arrowheads). Haematoxylin/eosin $(\times 160)$ 
Fig. 9. Photomicrographs of ovarian tissue (Platichthys flesus) showing vitellogenic oocytes unaffected by gross morphological changes. The oocytes are densely packed with numerous yolk granules, the nucleus intact containing nucleoli and the cytoplasm surrounded by a marked zona radiata and follicular layers Haematoxylin/eosin $(\times 160)$

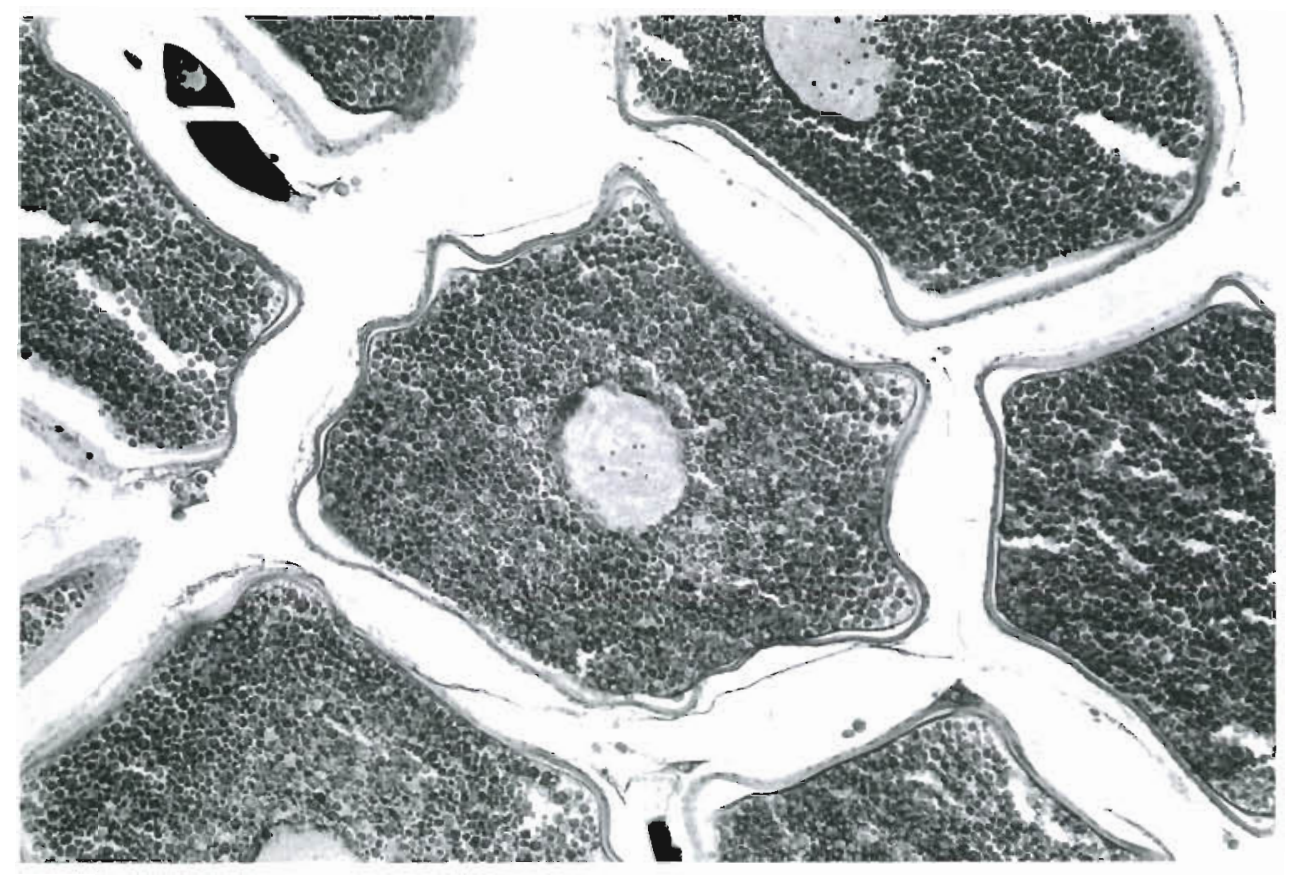

site; $F=21.3, p<0.05$; date; $F=80.1, p<0.05)$, the inter-site differences being restricted to significantly larger GSI-values in male flounders from the Tyne in April compared to those in Solway Firth fish (Tukey's, $\mathrm{p}<$ 0.05): A significant difference could also be found in December between the sites within the Tyne (Tukey's, $p<0.05$ )

\section{Hepatosomatic index}

The mean HSI-values of both female and male flounders varied significantly between site and sampling occasion (2-way ANOVA, site: $F=47.5$ [female], 31.5 [male], p < 0.05; date: $F=93.0$ [female], 14.6 [male], $p<0.05$ ) (Fig. 12). Thus, female and male flounder from all sites in the Tyne and at all sampling occasions, except for fernales in July (Tukey's, p > 0.05), exhibited mean HSI-values significantly larger than those of Solway fish, indicating increased liver weights in fish from the Tyne (Fig. 12). Apart from significantly lower mean HSI-values in male fish from Site T3 in the Tyne in December (Tukey's, p < 0.05) there were no differences detected between either males or females taken from sites within the Tyne (Tukey's, $p>0.05$ ).

\section{DISCUSSION}

This study provides further evidence that wild populations of flounder Platichthys flesus from the Tyne estuary, UK, which receives large inputs of sewage effluent, are showing elevated plasma concentrations of $v t g$, and are therefore exposed to oestrogenic substances (Sumpter \& Jobling 1995). Effects in the Solway Firth are less severe and this can be related to the lower input of sewage and other anthropogenic effluents in the Solway Firth. The presence of vtg was recorded in up to $50 \%$ of male fish from the Solway Firth and up to $94 \%$ of male fish from the Tyne estuary, indicating that, at the more fundamental levels of biological organisation, e.g. at the molecular and cellular levels of individual organisms, effects of environmental exposure to oestrogens may be widespread. At this level, there tends to be a great deal of similarity among vertebrate classes due to the extreme phylogenetic conservation of hormones and hormone receptors binding characteristics (Folmar et al. 1995, Heppell et al. 1995, Sumpter \& Jobling 1995, Kavlock et al. 1996). It is therefore reasonable to assume that other species, including both vertebrates and invertebrates, and in particular bottom-living, sedimentdwelling species, inhabiting waters receiving various amounts of oestrogens derived from sewage or other anthropogenic discharges, are also affected. The susceptibility of different species and/or sub-populations may make some more susceptible to the effects of environmental oestrogens than others (Petersen \& Korsgaard 1989, Hylland \& Braaten 1996, Steinmetz et al. 1997).

High levels of vtg in male rainbow trout have been shown to be accompanied by a decrease in testis growth and to affect spermatogenesis (Jobling et al. 1996). Although testis weight (e.g. GSI) was largely 

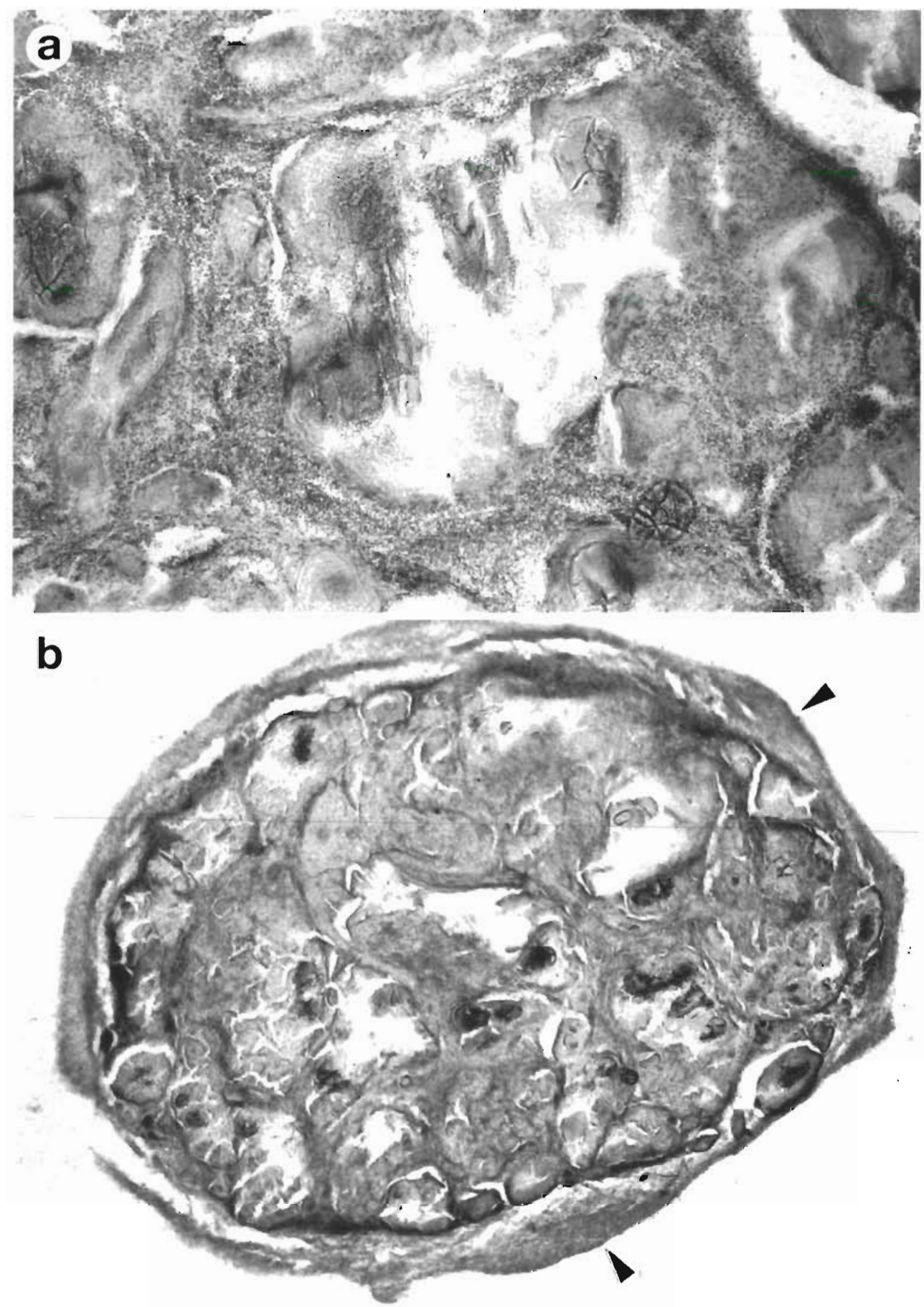

Fig. 10. Photomicrographs of ovarian tissue (Platichthys flesus) showing (a) degenerating oocytes (e.g. rupture of zona radiata, the breakdown of yolk granules and nucleus, and extensive infiltration of fibroblast-like cells) $(\times 160)$. (b) Aggregate of atretic oocytes encapsulated by several cell layers (arrowheads). Haematoxylin/eosin $(\times 25)$

unaffected in fish from the Tyne in this study, histological examinations revealed testis morphology that does not correspond with the description of normal teleost testis morphology (Barr 1963a, Htun-Han 1978a, Janssen et al 1996). Examined testes from the Tyne flounder had poorly organised seminiferous tubules consisting largely of connective tissue that, in turn, reduced the number of germ cells markedly Additionally, these testes showed remnants of sperma- tozoa/luminal debris in the seminiferous tubules, disrupted lobule walls, vacuolation and the frequent presence of amorphous eosinophilic precipitates. These effects are consistent with the effects observed in several teleost and avian species experimentally exposed to a range of sterolds and oestrogenic substances (e.g. some PCBs, $\beta$-HCH, chlordecane, 4-tert-pentylphenol) and some metals (Cohen 1946, Fagerlund \& McBride 1975, Goetz et al. 1979, Billard et al. 1981, Sangalang 

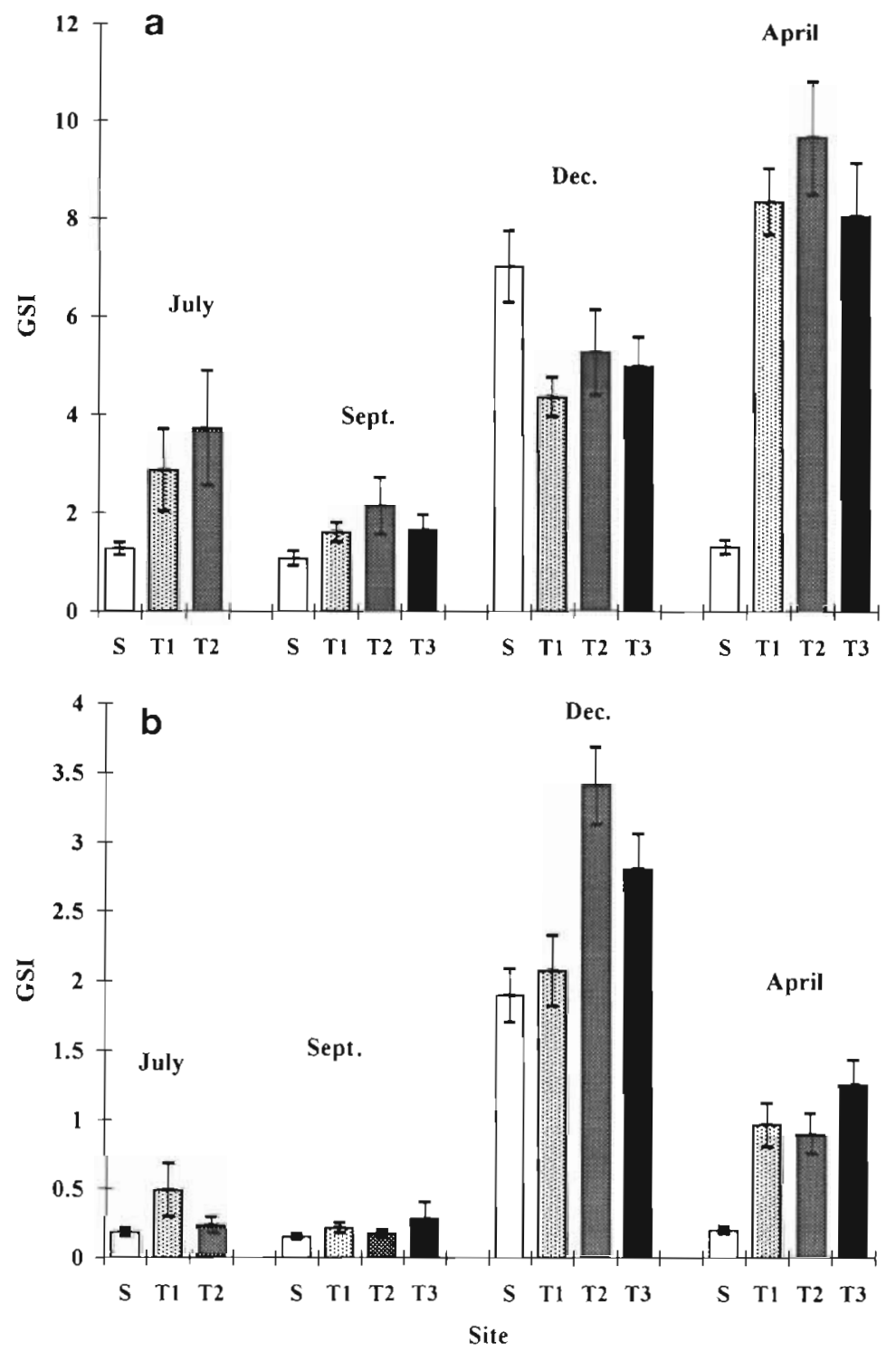

Fig. 11. Mean ( \pm SE) gonadosomatic index (GSI: gonad weight $[\mathrm{g}] /$ body weight [g]) of (a) female and (b) male flounders Platichthys flesus from sites in the Tyne Estuary (T1, T2, T3) and the Solway Firth (S)

stage of the reproductive cycle. Testes at the beginning of the annual reproductive cycle, from flounder showing the highest levels of plasma vtg, were the most severely affected and fully mature testes at the end of the annual reproductive cycle the least affected. Recovery of the highly degenerative testes found in May and September is unlikely to have occurred by December. The duration of exposure to oestrogenic sewage will be dependent on the movements of flounder. Although the flounder for most of the year is a relatively stationary species within the estuary, it migrates offshore during the winter months to spawn (Wheeler 1969). It seems likely that the sample examined in December comprised flounders migrating down the estuary to spawn at sea. These flounders would not have been subjected to high levels of sewage effluents during their reproductive development and this may provide an explanation for the presence of relatively healthy testes in December compared to other sampling occasions. Several workers have also demonstrated that the degree on inhibitory effects of testicular growth in rainbow trout Oncorhynchus mykiss and cod Gadhus morhua exposed to oestrogens (e.g. 17 $\beta$-oestradiol) and oestrogenic chemicals (e.g. alkylphenols, some PCBs) is both dose-dependent and affected by timing of exposure (Billard et al. 1981, Sangalang et al. 1981, Jobling et al. 1996).

Ovaries collected from the Tyne showing normal gross morphology corresponded to the description of ovaries reported in flounder (Janssen et al. 1995) and other flatfish (Barr 1963b, Htun-Han 1978b). In contrast, ovaries showing abnormal gross morphology revealed the breakdown of developing

et al. 1981, Sehgal \& Pandey 1984, Reel \& Lamb 1985 , Wester et al. 1985, Herman \& Kincaid 1988, Wester 1991, Dickerson 1997, Johnson et al. 1997, Gimeno et al. in press) and to the effects reported in wild male alligators exposed to dicofol, some DDEs and DDTs (Guillette et al. 1994). Subsequent investigations to this study have also recorded impaired spermatogenesis and fibrosis of the testicular tissue in wild walleyed pike Stizostedion vitreum and largemouth bass Micropterus salmoides inhabiting ponds receiving sewage discharges in Minnesota, USA (Folmar et al. $1997 a, b)$.

In this study, adverse effects in testes were observed to varying degrees depending on the individual and oocytes and conversion to fully formed corpora atretica (i.e. degenerating oocytes). A range of conditions has been correlated with increased incidence of oocyte atresia, including hypophysectomy (Barr 1963c, Khoo 1975), exposure to sex steroids and synthetic oestrogens (Bretschneider \& Duyvené de Wit 1947, Peluso et al. 1979, Iguchi 1985, Piferrer \& Donaldson 1992), several oestrogenic compounds (Buckler et al. 1981, Gray et al. 1989, Giesy et al. 1997, Johnson et al. 1997) and some metals (Kirubagaren \& Joy 1988). Increased incidence of oocyte atresia has also been reported in a variety of wild fish (e.g. largemouth bass, redbreast sunfish, bluegill- and brown bullet) from sites contaminated with PCBs, metals, bleached kraft mill efflu- 

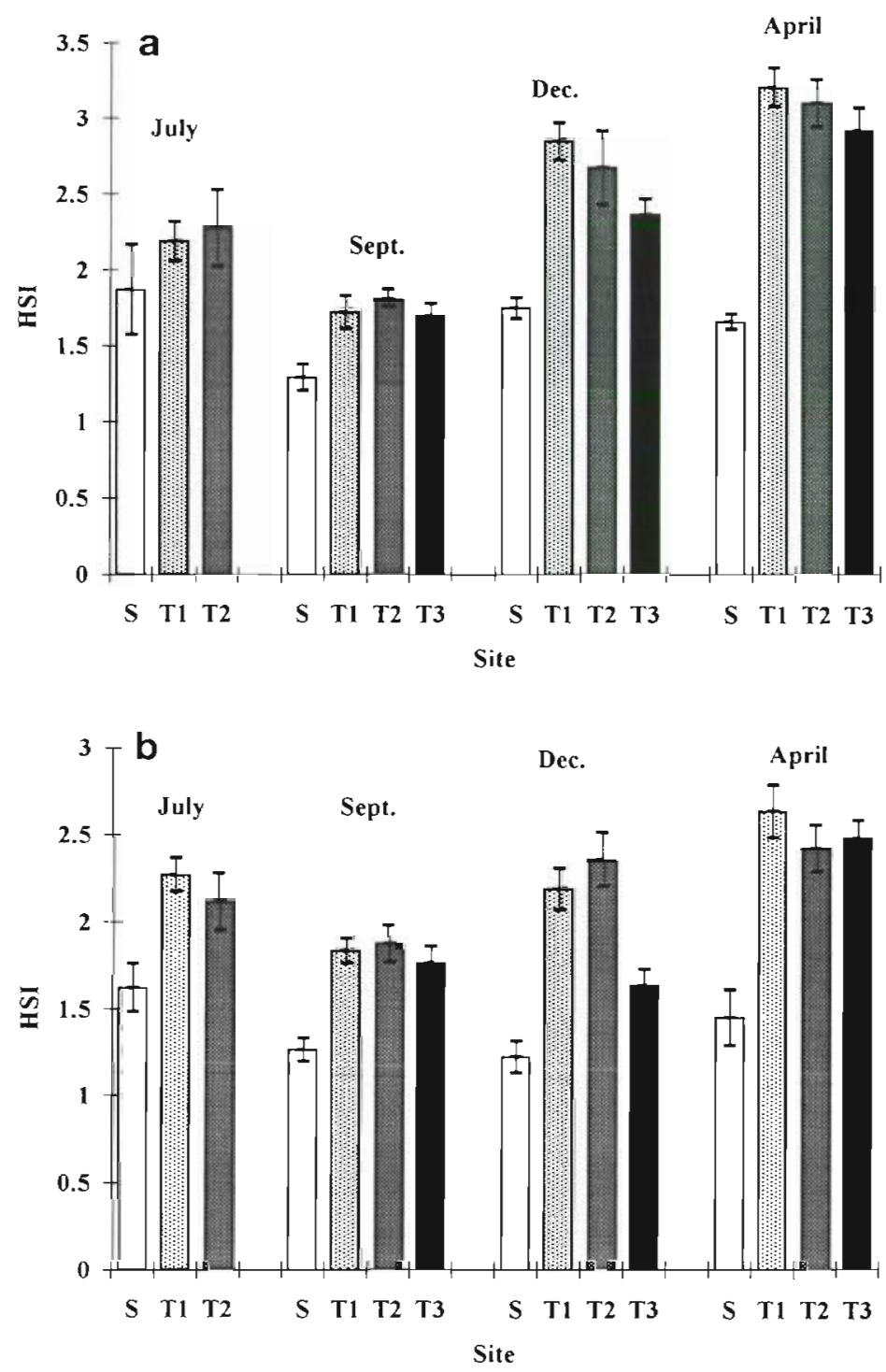

Fig. 12. Mean ( $t$ SE) hepatosomatic index (HSI: Liver weight $[\mathrm{g}] /$ body weight $(\mathrm{gl})$ of (a) female and (b) male flounders Platichthys flesus from sites in the Tyne Estuary (T1, T2, T3) and the Solway Firth (S)

ent, fuel components and mixed industrial wastewaters, and has been suggested to be related to the presence of chemical disrupters of the endocrine system (Greeley et al. 1997).

Grossly degenerating oocytes were absent in ovaries found in postspawning or previtellogenic phases (sampled in July) and were most frequent in ovaries in advanced vitellogenic phase (sampled in April), suggesting that the prevalence of degenerated oocytes correspond to the different stages in the reproductive cycle. This observation agrees with reports of other investigators who found atresia mainly restricted to yolked oocytes (Khoo 1975, Babu \& Nair 1983, Johnson et al. 1991).

Increases in HSI were observed both in male and female flounders exposed to sewage effluent. In- creases in liver weights (HSI) are associated with enhanced detoxification activities in response to the presence of toxic compounds, e.g. PAHs, PCBs (Janssen et al. 1996), cadmium (Pereira et al. 1992), crude oil (Truscott et al. 1992). They are also consistent with increasing levels of endogenous oestrogens in female fish during vtg synthesis (Janssen et al. 1995) and exposure to exogenous oestrogens in male fish, since oestrogen raises the amount of endoplasmatic reticulum in the liver, thus indicating enhanced protein (vtg) synthesis (Emmersen \& Emmersen 1976).

In addition to most UK rivers (Harries et al. 1996, 1997), the present study strongly suggests that at least some UK estuaries are also suffering severe contamination by oestrogenic substances. Moreover, the limited data indicate that flounder showing strong vitellogenesis are also suffering adverse reproductive effects that may or may not derive specifically from the action of environmental oestrogens. Although the implications of these observations for fish reproduction and population are not yet known, there must be some concern that flounders showing these effects may have reduced reproductive viability. The present study therefore suggests that further research on oestrogenic contamination of the aquatic environment needs to focus on the crucial relationship between 'early' changes at the biochemical and physiological level (e.g. vtg production), histological changes (e.g. pathological effects on the gonads) and the more serious consequences at the population and community levels (e.g. changes in fecundity and viability).

Acknowledgements. The authors gratefully acknowledge Dr Sylvia Gimeno, Toxicology Division, TNO, The Netherlands for valuable discussions on histopathology, Dr Trevor Booth, Dept of Biomedical Electron Microscopy Unit, and Mr Chris Rowland, Dept of Neurobiology, University of Newcastle for technical assistance. The manuscript was improved as a result of the comments received from the editor and referees; our thanks to them.

\section{LITERATURE CITED}

Ahel M, McEvoy J, Giger W (1993) Bioaccumulation of the lupophilic metabolites of nonionic surfactants in freshwater organisms. Environ Pollut 79:243-248

Babu N, Nair NB (1983) Follicular atresia in Amblypharnygodon chakaiensis. Z Mikrosk Anat Forsch 97:499-504

Barr WA (1963a) The endocrine control of the sexual cycle in the plaice, Pleuronectes platessa (L). III. The endocrine control over spermatogenesis. Gen Comp Endocrinol 3:21.6-225

Barr WA (1963b) The endocrine control of the sexual cycle in the plaice, Pleuronectes platessa (L). I. Cyclical changes in 
the normal ovary. Gen Comp Endocrinol 3:197-204

Barr WA (1963c) The endocrine control of the sexual cycle in the plaice, Pleuronectes platessa (L). II. The endocrine control of oogenesis. Gen Comp Endocrinol 3:205-215

Berge JA, Brevik EM (1996) Uptake of metals and persistent organochlorines in crabs (Cancer pagurus) and floundex (Platichthys flesus) from contaminated sediments: mesocosm and field experiments. Mar Pollut Bull 33:46-55

Billard R, Breton R, Richard M (1981) On the inhibitory effect of some steroids on spermatogenesis in adult rainbow trout (Salmo gairdneri). Can J Zool 59:1379-1487

Bretschneider JH, Duyvené de Wit JJ (1947) Sexual endocrinology of non-mammalian vertebrates. Elsevier Publisher Company, London

Bromage NR, Cumaranatunga R (1988) Egg production in the rainbow trout. Rec Adv Aquacult 3:65-138

Brotons JA, Olea-Serrano MF, Villalobos M, Pedraza V, Olea $N$ (1995) Xenoestrogens released from lacquer coatings in food cans. Environ Health Perspect 103:608-612

Buckler DR, Witt A Jr, Huckins J (1981) Acute and chronic effects of Kepone and mirex on the fathead minnow. Trans Am Fish Soc 110:270-280

Carlsen E, Giwercman A, Keiding N, Skakkebæk NE (1995) Declining semen quality and increasing incidence of testicular cancer: is there a common cause? Environ Health Perspect 103:137-139

Cohen $H$ (1946) Effects of sex hormones on the development of the platyfish, Platypoecilus maculatus. Zoologica NY Zool Soc 31:121-128

Colborn T, Clement C (1992) Chemically-induced alterations in sexual and functional development; the human and wildlife connection. Princeton Scientific, Princeton, NJ

Dickerson RL, Matter JM, Anthony AB, Sills-McMurry C (1997) Development and validation of biomarkers of endocrine disruption in wildlife: studies in avian, mammalian and reptilian species. In: Proceedings of the 7 th Annual Meeting of SETAC-Europe, 6-10 April, 1997, Amsterdam. SETACEurope, Brussels

Dodd JM (1983) Reproduction in cartilaginous fishes (Chondrichthyes). In: Hoar WS, Randall DJ, Donaldson EM (eds) Fish physiology, Vol IX, Reproduction, Part a, endocrine tissues and hormones. Academic Press Inc, London, p 31-95

Emmersen BK, Emmersen J (1976) Protein, RNA and DNA metabolism in relation to ovarian vitellogenic growth in the flounder Platichthys flesus (L). Comp Biochem Physiol 55B:315-321

Environmental Agency UK (1998) Endocrine-disrupting substances in the environment. What should be done? Environmental Issues Series, Consultative Report

EPA (Environmental Protection Agency) (1997) Special report on endocrine disruption: an effects assessment and analysis. EPA/630/R-96/012. Risk Assessment Forum, US Environmental Protection Agency, Washington, DC

Fagerlund UHM, MCBride JR (1975) Growth increments and some flesh and gonad characteristics of juvenile coho salmon receiving diets supplemented with $17 \alpha$-methyltestosterone. J Fish Biol 7:305-314

Folmar L, Denslow N, Reiskind N, Naylor C, Guillette L Jr (1997a) Sewage effluent as irrigation water? Some biological consequences. In: Proceedings of the SETAC 18th Annual Meeting, San Francisco, November 1997. SETAC, Pensacola

Folmar LC, Denslow ND, Wallace RA, LaFleur G, Gross TS, Bonomelli S, Sullivan CV (1995) A highly conserved Nterminal sequence for teleost vitellogenin with potential value to the biochemistry, molecular biology and pathology for vitellogenesis. J Fish Biol 46:255-263
Folmar L, Gray N, Netcalfe C, Enblom J, Reiskind N, Denslow $\mathrm{N}$, Guillette L Jr (1997b) The effects of sewage effluent on reproduction in carp and walleyed pike. In: Proceedings of the SETAC 18th Annual Meeting, San Francisco, November 1997. SETAC, Pensacola

Giesy JP, Miles-Richardson SR, Nicholas KM, Pierens SL, Snyder EM, Villeneuve DL (1997) Strategies for assessing potential for compounds to modulate endocrine function in aquatic organisms. In: Proceedings of the 7 th Annual Meeting of SETAC-Europe, 6-10 April, 1997, Amsterdam. SETAC-Europe, Brussels

Gimeno S, Komen H, Jobling S, Sumpter JP, Bowmer T (1997) Demasculinisation of mature male common carp, Cyprinus carpio, exposed to 4-tert-pentylphenol during spermatogenesis. Aquat Toxicol (in press)

Goetz FW, Donaldson EM, Hunter GA, Dye HM (1979) Effects of $17 \beta$-estradiol and $17 \alpha$-methyltestosterone on gonadal differentiation in the coho salmon, Oncorhynchus kisutch. Aquaculture 17:267-278

Goksøyr A, Beyer J, Egaas E, Grøsvik BE, Hylland K, Sandvik $M$, Skaare J (1996) Biomarker response in flounder (Platichthys flesus) and their use in pollution monitoring. Mar Pollut Bull 33:36-45

Gray LE Jr, Ferrell J, Ostby J, Rehnberg G, Linder R, Cooper R, Goldman J, Slott V, Laskey J (1989) A dose response analysis of methoxychlor-induced alterations of reproductive development and function in the rat. Fundam Appl Toxicol 12:92-108

Greeley MS Jr (1997) Oocyte atresia in fish as a biological indicator of aquatic contamination. In: Proceedings of SETAC 18th Annual Meeting, San Francisco, November 1997 SETAC, Pensacola

Guillette LJ Jr, Gross TS, Masson GR, Matter JM, Percival HF, Woodward AR (1994) Developmental abnormalities of the gonad and abnormal sex hormone concentrations in juvenile alligators from contaminated and control lakes in Florida. Environ Health Perspect 102:680-688

Harries JE, Sheahan DA, Jobling S, Matthiessen P, Neall P, Routledge EJ, Rycroft R, Sumpter JP, Tylor T (1996) A survey of estrogenic activity in United Kingdom inland waters. Environ Toxicol Chem 15:1993-2002

Harries JE, Sheahan DA, Jobling S, Matthiessen P, Neall P, Sumpter JP, Tylor T, Zaman N (1997) Estrogenic activity in five United Kingdom rivers detected by measurement of vitellogenesis in caged male trout. Environ Toxicol Chem 16:534-542

Harris CA, Henttu P, Parker HG, Sumpter JP (1997) The estrogenic activity of phthalate esters in vitro. Environ Health Perspect 105:802-811

Harrison PTC, Humfrey CDN, Litchfield $M$, Peakall D, Shuker LK (1995) Environmental oestrogens: consequences to human and wildlife. Institute for Environment and Health, University of Leicester

Heppel SA, Denslow ND, Folmar LC, Sullivan CV (1995) Universal assay of vitellogenin as a biomarker for environmental estrogens. Environ Health Perspect 103:9-15

Herman RL, Kincaid HL (1988) Pathological effects of orally administered estradiol to rainbow trout. Aquaculture 72 : $165-172$

Htun-Han M (1978a) The reproductive biology of the dab Limanda limanda (L) in the North Sea: seasonal changes in the testis. J Fish Biol 13:361-367

Htun-Han M (1978b) The reproductive biology of the dab Limanda limanda ( $\mathrm{L}$ ) in the North Sea: seasonal changes in the ovary. J Fish Biol 13:351-359

Hylland K, Braaten B (1996) Kartlegging av mulige ostrogenlignende effekter i miljøet i Norge a) biologiske effekter. 
NIVA Rapport. Lnr 3422-96, Norsk institutt for vannforskning Oslo

Iguchi T (1985) Occurrence of polyovular follicles in ovaries of mice treated neonatally with diethylstılbestrol. Proc Jpn Acad Ser B Phys Biol Sci 61:288-291.

Janssen PAH, Lambert JGD, Goos HJT (1995) The annual ovarian cycle and the influence of pollution on vitellogenesis in the flounder, Platichthys flesus (L). J Fish Biol 47:509-523

Janssen PAH, Monteiro PMRR, Lambert JGD, Goos HJT (1996) IV. Spermatogenesis, testicular steroidogenesis and plasma steroid profiles in the male flounder, Platichthys flesus (L), during the annual reproductive cycle and after long-term exposure to pollute harbour sediment. In: Janssen P (ed) Reproduction of the flounder, Platichthys flesus ( $\mathrm{L}$ ), in relation to environmental pollution. Doctoral thesis, University of Utrecht, p 55-82

Jobling S, Nolan M, Brighty $G$, Tylor CR, Sumpter JP (1997) British rivers contain a high proportion of inter-sex roach (Cyprinidae, Pisces). In: Proceedings of the 7th Annual Meeting of SETAC-Europe, 6-10 April, 1997, Amsterdam. SETAC-Europe, Brussels

Jobling S, Reynolds $T$, White R, Parker MG, Sumpter JP (1995) A variety of environmentally persistent chemicals, including some phthalate plasticizers, are weakly estrogenic. Environ Health Perspect 103:582-587

Jobling S, Sheahan D, Osborn JA, Matthiessen P, Sumpter JP (1996) Inhibition of testicular growth in rainbow trout (Oncorhynchus mykiss) exposed to estrogenic alkylphenolic chemicals. Environ Toxicol Chem 15:194-202

Johnson LC, Metcalfe C, Kiparissis Y, Balch G, Ward GS, Wheat J, Liu J (1997) Partial life-cycle studies using the estuarine fish sheepshead minnow to evaluate the potential and estrogenic effects of a nonylphenol ethoxylate surfactant. In: Proceedings of SETAC 18th Annual Meeting, San Francisco, November 1997. SETAC, Pensacola

Johnson LL, Casillas E, Myers MS, Rhodes LD, Olson OP (1991) Patterns of oocyte development and related changes in plasma of $1.7 \beta$-oestradiol, vitellogenin and plasma chemistry in English sole Parophrys vetulus Girard. J Exp Mar Biol Ecol 152:161-185

Kavlock RJ, Daston GP, DeRosa C, Fenner-Crisp P, Gray LE, Lucier G, Luster M, Mac MJ, Maczka C, Miller R, Moore J, Rolland R, Scott G, Sheehan DM, Sinks T, Tilson HA (1996) Research needs for the risk assessment of health and environmental effects of endocrine disrupters: a report of the U.S. EPA-sponsored Workshop. Environ Health Perspect 104:715-740

Khoo KH (1975) The corpus luteum of goldfish (Carassius auratus L.) and its functions. Can J Zool 53:1306-1323

Kirubagaran R, Joy KP (1988) Toxic effects of mercuric chloride, methylmercuric chloride and Emisan 6 (an organic mercurlal fungicide) on ovarian recrudescence in the catfish Clarias batrachus (L). Bull Environ Contam Toxicol 41:902-909

Kisilevsky R (1994) Amyloidosis. In: Rubin E, Farber JL (eds) Pathology. JB Lippincott, Philadelphia, p 1164-1174

Korach KS, McLachlan JA (1995) Techniques for detection of estrogenicity. Environ Health Perspect 103:5-8

Lye CM, Frid CLJ, Gill ME, McCormick D (1997) Abnormalities in the reproductive health of flounder. Platichthys flesus exposed to effluent from a sewage treatment work. Mar Pollut Bull 34:34-41

McLachlan JA (1981) Estrogens in the environment. Elsevier North Holland Inc, New York

McLachlan JA (1985) Estrogens in the environment. II. Influences of development. Elsevier Science, New York

Peluso JJ, Brown I, Steger RW (1979) Eftects of cyproterone acetate, a potent antiandrogen, on the preovulatory folli- cle. Biol Reprod 21:929-936

Pereira JJ, Ziskowski J, Mercaldo-Allen R, Kuropat C, Luedke D, Gould E (1992) Vitellogenin in winter flounder (Pleuronectes americanus) from Long Island Sound and Boston harbour. Estuaries 15:289-297

Petersen I, Korsgaard B (1989) Experimental induction of vitellogenin synthesis in eel (Anguilla anguilla) adapted to seawater or freshwater. Comp Biochem Physiol 93B:57-60

Piferrer F, Donaldson EM (1992) The comparative effectiveness of the natural and a syrthetic estrogen for the direct feminisation of chinook salmon (Oncorhynchus tshawytscha). Aquaculture 106:183-193

Purdom CE, Hardiman PA, Bye VJ, Eno NC, Tyler CR, Sumpter JP (1994) Estrogenic effects on effluents from sewage treatment works. Chem Ecol 8:275-285

Reel JR, Lamb JC (1985) Reproductive toxicology of chlordecone (kepone). In: Thomas JA (ed) Endocrine toxicology. Raven Press, New York, p 375-392

Sangalang GB, Freeman HC, Crowell R (1981) Testicular abnormalities in cod (Gadhus morphua) fed Arochlor 1254. Arch Environ Contam Toxicol 10:617-626

Sehgal R, Pandey A (1984) Effect of cadmium chloride on testicular activities in guppy Lehistes reticulatus. Comp Physiol Ecol 9:225-230

Sharpe RM, Skakkebæk NE (1993) Are oestrogens involved in falling sperm counts and disorders of the male reproductive tract? Lancet 341:1392-1395

Solway Firth Partnership (1996) Solway Firth Review. Nautilus Consultants (ed). Dumfries and Galloway Council, Dumfries

Soto AM, Sonnenschein C, Chung KL, Fernandez MF, Olea $N$, Serrano FO (1995) The E-screen assay as a tool to identify oestrogens: an update on oestrogenic environmental pollutants. Environ Health Perspect 103:113-122

Steinmetz R, Brown NG, Allen DL, Bigsby RM, Ben-Jonathan $N(1997)$ The environmental estrogen Bisphenol-A stimulates prolactin release in vitro and in vivo. Endocrinology 138:1780-1786

Sumpter JP, Jobling S (1995) Vitellogenesis as a biomarker for estrogenic contamination of the aquatic environment. Environ Health Perspect 103:173-178

Toppari J, Larsen JC, Christiansen P, Giwercman A, Grandjean

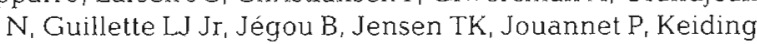
$\mathrm{N}$, Leffers H, McLachlan JA, Meyer O, Müller J, Rajpert-De Meyrts E, Scheike T, Sharpe R, Sumpter J, Skakkebæk E (1995) Male reproductive health and environmental chemicals with estrogenic effects. Miljøprojekt 290. Danish Ministry of Energy and Environment, Copenhagen

Truscott B, Idler DR, Fletcher GL (1992) Alterations of reproductive steroids of male winter flounder (Pleuronectes americanus) chronically exposed to low levels of crude oil in sediments. Can J Fish Aquat Sci 49:2190-2195

Waldock MJ, Desbrow C, Sheahan. D, Blackburn M, Routledge EJ, Sumpter JP, Brighty G (1997) Chemical analysis of hormone mimicking chemicals in UK waters. In: Proceedings of endocrine disrupters in the environment. 20-21 May, 1997, IBC UK Conferences Limited, London.

Wester PW (1991) Histopathological effects of environmental pollutants $\beta$-HCH and methyl mercury on reproductive organs in freshwater fish. Comp Biochem Physiol 100C: $237-239$

Wester PW, Canton JH, Bisschop A (1985) Histopathological study of Poecilia reticulata (guppy) after long-term. $\beta$-Hexachlorocyclohexane exposure. Aquatic Toxicol 6:271-296

Wheeler A (1969) The fisheries of the British Isles and NorthWest Europe; the flatfish. Macmillan \& Co Ltd, London

Zar JH (1984) Biostatistical analysis, 2nd edn. Prentice-Hall International Publ, London 